\title{
Flexibility and Current Housing Conditions in Serbia: A Case Study of the City of Nis
}

\author{
Milica ZIVKOVIC*, Slavisa KONDIC, Milan TANIC, Marija STAMENKOVIC, Aleksandar KEKOVIC
}

\begin{abstract}
This paper proposes a method for evaluation of internal apartment flexibility in multi-family housing with respect to its specific application to contemporary residential architecture of the city of Nis (Southeastern Serbia). The presented method is based on an analysis, in which the subject of evaluation is assessed through the spatial criteria that are directly related to the concept of flexibility. Obtained qualitative results sum up the observations of the current methodology of architectural design for a specific urban environment in the context of the circumstances of the housing market and the basic characteristics of households in Serbia as a country in transition. The ultimate goal of this research is to create a program basis of flexible housing that would be implemented in the process of sustainable design and could be applied both at the local and national level, providing guidelines on global housing development as well.
\end{abstract}

Keywords: apartment; flexibility; housing conditions; sustainability

\section{INTRODUCTION}

Society is never static; human civilization has an integral tendency towards change - usually towards progress and improvements in the condition of human existence [1]. The evolution of social behaviour leads to new conceptual solutions of contemporary housing, such as new design principles of living environment and its immediate surroundings.

Several elements cause movements within the programs and functions of housing, including the phenomenon of increased social differentiation, diverse perceptions of home, lesser presence of a traditional family life, the tendency of housing-work integration as well as the general unpredictability of the course of changes development over time [2]. It is, therefore, necessary to organize the residential areas in accordance with the principles of clearly defined flexibility, which allows the application of various housing concepts. In addition, it actively corresponds to continuous changes in all spheres of society. Increasing the flexibility and extending the useful life of the building increase its use value [3].

\section{OBJECTIVES}

An apartment represents the basic physical framework for a family. Family, as the primary social group should, through its development phase, respond to the changing needs of the demographic, economic, environmental and technological aspects of society. The aim of this research is to promote the principles of a flexible design of a residential unit (internal flexibility), which is based on the concept of interdependence of characteristic design factors. Internal flexibility implies the possibility of changing the structure and organization within a fixed frame of an apartment and is the most common example of flexibility in Serbia [4].

The application of the method of a multilateral analysis, where the subject of evaluation is assessed through several criteria of flexibility, gives the judgment of the flexible potentials of a living space. Systematization of the results defines the conceptual basis to the methodology of a flexible design and provides further guidance for the improvement of sustainable housing.
The evaluation of apartment flexibility in multi-family buildings is a complex and demanding process, which cannot be implemented without the use of the results of longstanding research in the field of housing. Previous studies of the flexible housing within the academic framework of the Republic of Serbia are quite deficient. Hence, the insights expressed in this paper are largely based on the current international research and data taken from older domestic/local literature.

\section{HOUSING POLICY AND THE MAIN FEATURES OF THE HOUSEHOLDS IN SERBIA}

Over the past half century, Serbia has undergone radical changes in all areas of social life. The progress periods alternated with the periods of major economic, political and social crises. Historical upheavals influenced the development process of a modern society as well as that of the family structure, previously defined as the basic social cell. Influenced not only by modernization, but also destabilizing factors in the observed time continuum, households gradually changed both their structure and population size.

An analysis of trends and changes in household size suggests that convergence to smaller, nuclear households is slowly occurring in modern developing countries. According to convergence theory, households become less extended, more nuclear, and smaller as societies industrialize and urbanize [5].

In 2012, the Republic Bureau of Statistics published the results of the "2011 Census of population, households and dwellings in the Republic of Serbia" [6]. This publication researched the structure of the Serbian households according to the number of members as well as the average size by the settlements. Based on the results of the 2011 Census, Serbia has a total of 2487886 households. With respect to the number of members per household, the most common are the two-member households $(25,6 \%)$, followed by single-person households $(22,3 \%)$, three-member households $(19,2 \%)$ and fourmember households $(18,3 \%)$. The share of households with more than four members is much lower. The average household has 2,88 members.

Major changes in the structure of households in terms of the number of members, can be observed in the single- 
member and four-member family. By comparing the 2002 Census [7] and the 2011 Census, the percentage of the single-person households increased from $20 \%$ to $22,3 \%$, while the four-member households decreased from $21,3 \%$ to $18,2 \%$.

The tendency of reducing the number of household members on the territory of Serbia is shown in Fig. 1. The average number of household members was reduced from 4,39 members in 1948 to 2,88 members in 2011 [8]. Furthermore, the aging population in the past half century in central Serbia significantly influenced the decline in average household size.

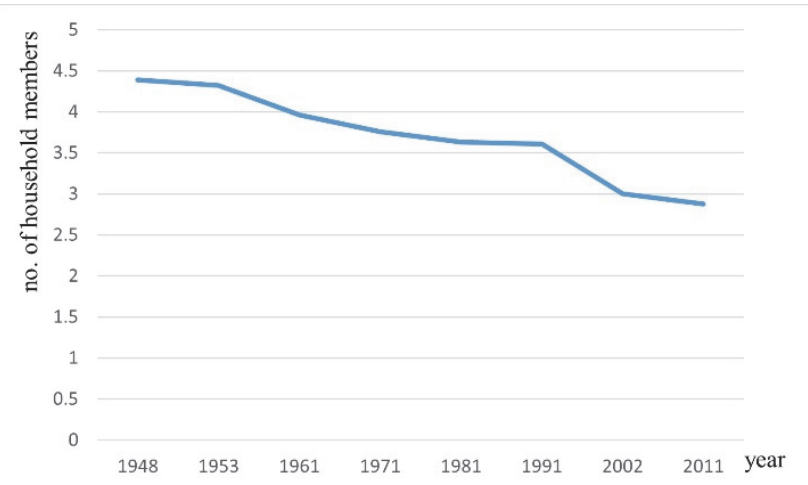

Figure 1 The average number of household members by years in Serbia

In a well-functioning housing market, the interplay of demand and supply forces determines housing outcomes: prices and rents which are indicative of housing affordability. These outcomes include prices, quantitative and qualitative features of the housing stock, tenure choice, residential mobility and levels of investment. Due to the lack of comprehensive housing policy in Serbia in the last twenty years, radical changes occurred in the housing market. Even with the substantial increase of housing needs in recent years, there has been no comprehensive organized resolution of problems in the housing sector.

Overall, the state of the housing sector has drastically changed in Serbia in the last two decades. For example, the housing sector has almost completely undergone privatization. In addition, the financing source behind the public housing fund has been eliminated. Moreover, the State has almost completely withdrawn from the housing sector, driven in part by the global ideological assumptions that advocate leaving the housing sector to the housing market and its laws, in particular after it had undergone a significant housing deficit [9].

Transitional forms of architecture transcend national boundaries and are becoming a part of a new world trends. Nowadays, Serbia is oriented to the market economy and the process of European integrations. The latter inevitably affects the transformation of all segments of society, requiring significant time for harmonization of the various changes. However, the implementation of advanced policy and construction that would improve the living conditions has been slow due to the excessive focus on making changes in regulations for the housing sector based on significant social changes.

The major problem from the standpoint of the housing sector's development is the fact that after massive and almost free of charge housing privatization in the early $90 \mathrm{~s}$, the public housing fund almost completely disappeared [9].
At the same time the privatization deteriorated the quality of housing development primarily expressed through the size and bad functional arrangement of the apartments, ignoring the minimum requirements of living comfort.

Based on the 2002 Census, measured by the standard of "one room per person", $18 \%$ of the population lived in overcrowded dwellings with more than two people per room. Measuring indicators showed that $30 \%$ of homes did not meet the minimum of European standards of $15 \mathrm{~m}^{2}$ per inhabitant. In addition, there were 17921 non-standard residential spaces (occupied business premises and premises occupied by necessity), inhabited by 54169 people. The housing deficit is also expressed through the lack of large housing units, the share of which is lower than that of the households with more than four members, as well as through a slightly smaller deficit of the smallest apartments [6].

According to the 2011 Census, the average apartment area in the urban settlements of Serbia amounts to 64,21 $\mathrm{m}^{2}$. The average apartment size is noticeably lower than that in the EU countries where the size area is ranging from $77 \mathrm{~m}^{2}$ in Finland to $125 \mathrm{~m}^{2}$ in Luxembourg. The apartments in the United States are even larger with an average size of $145 \mathrm{~m}^{2}[10]$.

\section{METHODOLOGICAL FRAMEWORK}

In order to define a possible method for evaluating the flexible potentials of an apartment, the following research steps should be considered:

- identifying the physical design aspects relating to the spatial flexibility of the apartment,

- determining variables for each individual aspect of flexibility,

- analysing the spatial characteristics of the apartment according to the selected evaluation criteria,

- examining the effect of various combinations of spatial variables on the achieved level of flexibility,

- defining the program basis of flexible housing.

The main criteria for determining the apartment's usevalue are housing needs and the level of their fulfilment through the spatial organization of inner space. In addition, assumed measurable aspects that largely affect the flexibility and consequently the use-value of the apartment are the following:

(a) outward orientation,

(b) layout geometry,

(c) structure and size of the flat,

(d) disposition of the entrance,

(e) disposition of the technical core,

(f) structural assembly [11].

In the assessment of the quality of achieved design, it is also necessary to identify both the evaluation criteria, and the features of the apartment's arrangement based on which the individual design is evaluated. This paper discusses the following physical criteria that determine the quality of the internal flexibility:

- degree of the actual freedom of interior space, i.e., the extent to which the organization of interior space is determined by position of the fixed elements in the plan, - potential for a multi-functional use of space, i.e., the possibility of changes in the room functions without changing their spatial dimensions, 
- changes in the number and size of rooms, i.e., the possibility of alternative partition positioning [12].

The achieved degree of flexibility is identified in accordance with established differences in the quality and use-value of the apartment.

\section{CRITERIA ANALYSIS}

In order to comprehend the actual planning and construction policy of the Republic of Serbia, seen from the aspect of flexibility, the examples of contemporary residential architecture in the city of Nis (Southeastern Serbia) are taken into consideration. The research includes a sample of 20 multi-family residential buildings constructed in the period of $2000-2015$. The buildings are located in the central city area where high population density and frequent movement in population structure impose a requirement for functional sustainability of the living environment. This period is characterized by dominant private housing development conducted without the usage and control of appropriate technical standards.

The apartments in question were designed for the traditional "nuclear" family structure. The analysis of flexible potentials of the individual housing units within the representative examples of local residential architecture is conducted according to the adopted evaluation model, previously defined in the study.

The family represents a product of evolution, transformable unit that adapts to the influences from outside and inside, which experiences significant shifts in each transitional stage within one generation. Therefore, the dynamic family structure necessitates the variable structure of the apartment. Flexible spatial organization should provide an elastic structure of the flat that would accommodate the requirements of dynamic changes in the household within the adopted spatial norms defined as the living standards. The implementation of standards is provided at certain time phases that coincide with the developmental stages of the family, ranging from maximum to minimum standards and vice versa (from increase to decrease in the family structure).

The basic facts of family lifecycle and economic reality suggest that the apartment must be the developmental synthesis that responds to demographic, economic and social needs. Changes within a family are caused primarily by the developmental lifecycle stages, i.e., birth, growth and departure of children from the parent family. For the family at an early stage of development (either a young couple without children or a young couple with a small child) the required structure is a two-room apartment, i.e., one-bedroom apartment. However, if the apartment is not flexible enough, the precondition of provided sleeping space for each member in further development stages of the family will not be fulfilled. From this perspective, the flexibility of the structure is justified starting from a three-member family, which can be defined as the "biological minimum" of flexibility.

According to the 2011 Census the presence of three $(21,71 \%)$ and four-member households $(21,06 \%)$, in the city of Nis is well-balanced so both family structures are taken into consideration. For this reason, the initial types of a two-room and two and a half-room apartment are part of the sampled material (a half-room in national regulations refers to a room for one person). The functional and spatial capacity of this apartment types has to respond to the needs of a growing family structure, i.e., providing one more room.

In accordance with the development stages of the family group, increasing of the apartment's initial structure (number of rooms) requires the identification of minimum spatial conditions of living comfort that must be fulfilled in its extensive phase. As three-member households require two and a half room apartments and four-member households require a three-room apartments, it is necessary that the initial structure of two-room and two and a half room apartments fulfil the requirement of a minimum size area of the higher category. According to the "Ordinance on the conditions and standards for the design of residential buildings and apartments" [13], the minimum size of two and a half room apartments is $58 \mathrm{~m}^{2}$ and $66 \mathrm{~m}^{2}$ for threeroom apartments (Tab. 1).

Table 1 Overview of the flat types and the allowed minimum areas of the flat and its individual facilities

\begin{tabular}{|c|c|c|c|c|c|c|c|c|c|}
\hline \multirow{2}{*}{$\begin{array}{l}\text { type of } \\
\text { flat }\end{array}$} & \multicolumn{4}{|c|}{ residential premises $/ \mathrm{m}^{2}$} & \multicolumn{4}{|c|}{ utility premises $/ \mathrm{m}^{2}$} & \multirow{2}{*}{$\begin{array}{l}\text { total } \\
\text { floor } \\
\text { area } \\
/ \mathrm{m}^{2}\end{array}$} \\
\hline & $1 r^{*}$ & br1 & br2 & $\mathrm{dn}$ & $\mathrm{kc}$ & $\mathrm{pt}$ & pt & wc & \\
\hline $\begin{array}{l}2 \text { room } \\
\text { flat }\end{array}$ & 16 & 11 & & 4,0 & 4,0 & 0.6 & 3,5 & & 48 \\
\hline $\begin{array}{l}2,5^{* *} \\
\text { room } \\
\text { flat }\end{array}$ & 16 & 11 & 7 & 4,0 & 5,5 & 0.7 & 3,5 & 1,2 & 58 \\
\hline $\begin{array}{l}\text { 3room } \\
\text { flat }\end{array}$ & 16 & 11 & $7 \times 2$ & 4,0 & 6,0 & 0,7 & 3,7 & 1,2 & 66 \\
\hline \multicolumn{10}{|c|}{$\begin{array}{l}\text { *1r - living room, br - bedroom, dn - dinning, kc - kitchen, pt - pantry, } \\
\text { bt - bathroom } \\
\text { **according to the current categorization in Serbia, a half room } \\
\text { represents one-person bedroom }\end{array}$} \\
\hline
\end{tabular}

According to the guidelines, these areas are adopted as the absolute minimum areas to allow both physical comfort as well as the transformation from a lesser to a higher apartment structure (with one more room). Within the research of functional and spatial sustainability of realized solutions, defined dimensional frameworks for individual apartment facilities are also taken into consideration.

\begin{tabular}{|} 
Table 2 Review of the spatial aspects of flexibility \\
\begin{tabular}{|c|c|c|c|c|c|}
\hline \multicolumn{7}{|c|}{ SPATIAL ASPECTS OF FLEXIBILITY } \\
\hline $\begin{array}{c}\text { orientation } \\
\text { (A) }\end{array}$ & $\begin{array}{c}\text { geometry } \\
(\mathrm{B})\end{array}$ & $\begin{array}{c}\text { size } \\
(\mathrm{C})\end{array}$ & $\begin{array}{c}\text { entrance } \\
(\mathrm{D})\end{array}$ & $\begin{array}{c}\text { Tech. } \\
\text { core }(\mathrm{E})\end{array}$ & $\begin{array}{c}\text { structure } \\
(\mathrm{F})\end{array}$ \\
\hline 1 one sided & 1 compact & $\begin{array}{c}1< \\
\min \end{array}$ & 1 central & 1 central & 1 frame \\
\hline 2 two sided & 2 jagged & $\begin{array}{c}2> \\
\text { min }\end{array}$ & $\begin{array}{c}2 \\
\text { peripheral }\end{array}$ & $\begin{array}{c}2 \\
\text { peripheral }\end{array}$ & $\begin{array}{c}2 \text { bearing } \\
\text { wall }\end{array}$ \\
\hline 3 three side & & & & & $\begin{array}{c}3 \\
\text { composite }\end{array}$ \\
\hline
\end{tabular}
\end{tabular}

The individual housing units (524 items) are evaluated by a multi-criteria analysis in order to identify the degree of initial structure flexibility. Spatial features of the apartment defined as fixed, unchanging aspects are considered as well. Tab. 2 gives an overview of the various characteristics of the individual factors of flexibility which 
are marked by the corresponding symbols. Variable models composed of fixed plan determinants are analysed and compared including their correlation with the actual degree of flexibility.

For easier overview of the evaluation results, two reference levels of flexibility are adopted. Level I indicates that flexibility can be achieved only through the multifunctional use of space, without significant intervention in the plan, while the requirement of increasing the initial apartment's structure is impossible to achieve. Level II indicates that the changes in the number and size of rooms can be achieved through the spatial reorganization of the plan. The levels are determined by previously defined physical criteria of layout flexibility.

Fig. 2 shows the method of the analysis which includes the identification of spatial aspects within the pre-defined categories and determining the degree of internal flexibility by subjective evaluation of spatial and functional potentials of the plan.
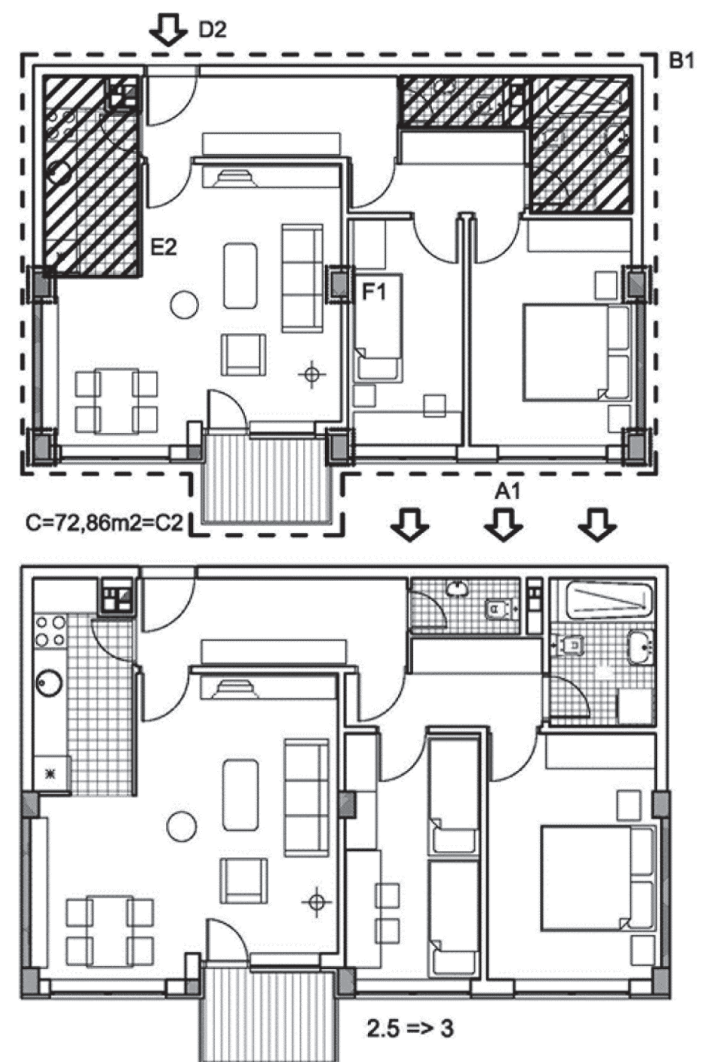

Figure 2 Evaluating method applied to a specific apartment (drawn by the authors)

During evaluation, the general guidelines of the "Ordinance on the Conditions and Standards for the Design of Residential Buildings and Dwellings" have been taken into consideration [13].

Tab. 3 provides a size overview of the apartment's facilities after reorganization of the space in order to increase its structure. Since the new design corresponds to the Regulations requirements, in dimensional and functional terms alike, it may be concluded that the initial structure has flexible features of second degree, i.e., it is possible to increase the apartment's structure without compromising the quality of housing.
Table 3 Size overview for analysed example before and after space rearrangement

\begin{tabular}{|l|l|c|c|}
\hline $\mathrm{N}^{\mathrm{O}}$ & Flat room and spaces & $\begin{array}{c}\text { before intervention / } \\
\mathrm{m}^{2}\end{array}$ & $\begin{array}{c}\text { after intervention } \\
\left(\mathrm{m}^{2}\right.\end{array}$ \\
\hline 1 & Entrance & 7,07 & 7,07 \\
\hline 2 & Living room & 23,41 & 22,32 \\
\hline 3 & Kitchen & 6,14 & 6,14 \\
\hline 4 & Bathroom & 4,56 & 4,56 \\
\hline 5 & WC & 1,79 & 1,79 \\
\hline 6 & Bedroom1 & 12,69 & 12,69 \\
\hline 7 & Bedroom 2 & 9,89 & 10,98 \\
\hline 8 & Inner hallway & 4,19 & 4,19 \\
\hline 9 & Terrace & 3,12 & 3,12 \\
\hline 10 & P total & 72,86 & 72,86 \\
\hline
\end{tabular}

Tab. 4 provides an overview of specific spatial factors that represent the appropriate configuration of variables (one sided orientation (A1), compact geometry (B1), floor area above the minimum (C2), peripheral entrance (D2), peripheral tech. core (E2), frame structure (F1)) and determine the degree of flexibility. In this case, the second, i.e., the highest degree of flexibility was achieved.

Table 4 Specific spatial configuration and appropriate level of flexibility

\begin{tabular}{|c|c|}
\hline Spatial factors configuration & \\
\hline A1 & \\
\hline B1 & \\
\hline C2 & II \\
\hline D2 & \\
\hline E2 & \\
\hline F1 & \\
\hline
\end{tabular}

\section{FINDINGS}

The systematization of obtained data of the structural apartment typology within the defined sample leads to a conclusion that the most common apartment types are tworoom apartments with 29,38\% (302 units), followed by two and a half-room apartments with $21,60 \%$ (222 units), one and a half room apartments with 16,25\% (167 units) and three-room apartments with 11,77\% (121 units, see Fig. 3).

Other typological structures are less represented. The apartments are usually designed for conventional family groups but can accommodate varying categories of family groups with temporary habitation. Consequently, the presence of two-room flats is increased within the typical floor plan. Low purchasing power of the population is another reason behind the market sales of apartments that have a smaller structure and an inflexible physical capacity that cannot be adjusted to user's needs.

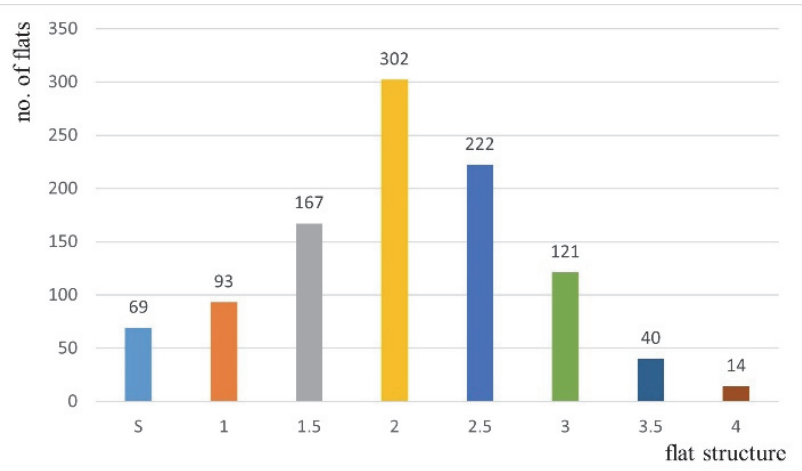

Figure 3 Percentage share of typical apartment structure 
Fig. 4 shows the percentage share of individual spatial categories for defined variables of flexibility. In the analysed sample, the most common are the apartments with one-side orientation (315 units, 60,11\%), while the multilateral orientation is less common primarily due to the prescribed urban conditions in the central city zone of block building construction. The main characteristics of actual city planning policy include the chaotic residential development in both the central and the suburban city areas on small and inadequate building plots as well as the neglected construction quality caused by investors' desire for large and fast profits. Furthermore, a decrease of output facades reduces opportunities for a flexible organization of the apartment. The flexible potentials of spatial design are limited by the fact that living facilities may be positioned only along one side of the building facade, so the plan variations are reduced to a minimum.

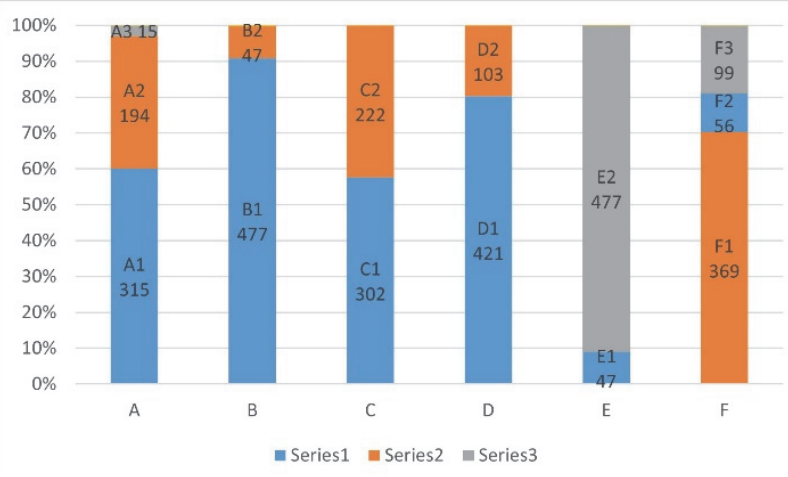

Figure 4 Percentage share of individual variables of flexibility

An apartment with the characteristics of flexibility should be designed in a more compact and simple form, without any breaks and changes in the dimensions, as thus its redistribution is much simpler and more diverse. In this particular case, $90,03 \%$ of apartments (477 units) have a compact, simple form so the possibilities of space redistribution, multi-functionality and changes in the number and size of the rooms are greater.

In practice, though, the problem of additional space for sleeping is often solved at the cost of reducing the quality of organizational and dimensional parameters such as size, connections and relationships of individual rooms, zoning concepts, etc. A multi-purpose living room with an additional sleep function is usually a solution for overcoming the problem of room deficit. For most tenants, providing a larger number of beds in the same area is more important than that of the dimensional and organizational quality of the flat.

However, contemporary housing criteria find this approach is to be unacceptable, especially in the case of the structure of larger flat. Namely, the flat with its size and structure must meet the family needs as defined in the "Ordinance on the Conditions and Standards for the Design of Residential Buildings and Flats". Fig. 5 and Fig. 6 present the results of the flat size analysis conducted within the sampled material. These values are compared to the minimum area size adopted within the concept of flexibility. The $67,88 \%$ of two-room flats and $28,83 \%$ of two and half-room flats have smaller sizes compared to defined minimal values. Moreover, in many cases the area size does not correspond to the prescribed minimum value for the initial structure of the apartment. This is the result of customers' low economic power. While they purchase apartments inadequate to the initial family structure, the discrepancy increases in parallel with the family expansion during the flat exploitation.

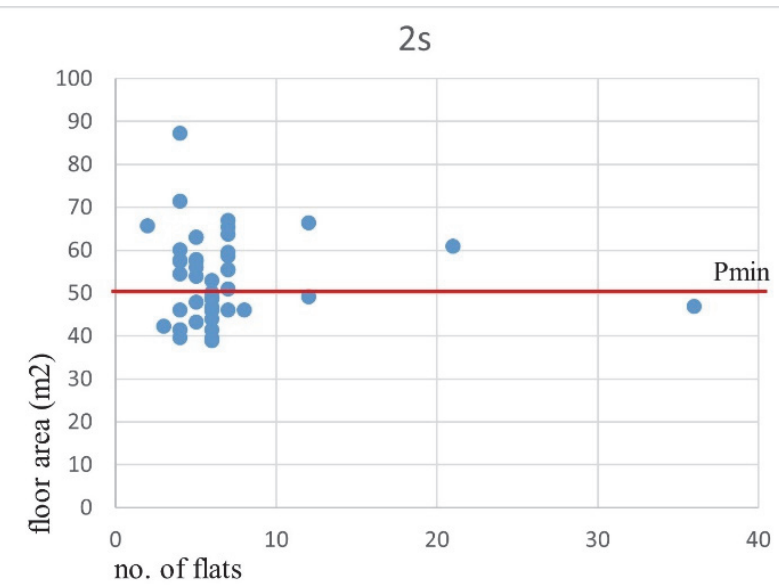

Figure 5 Review of the flat sizes within two-room apartment sample

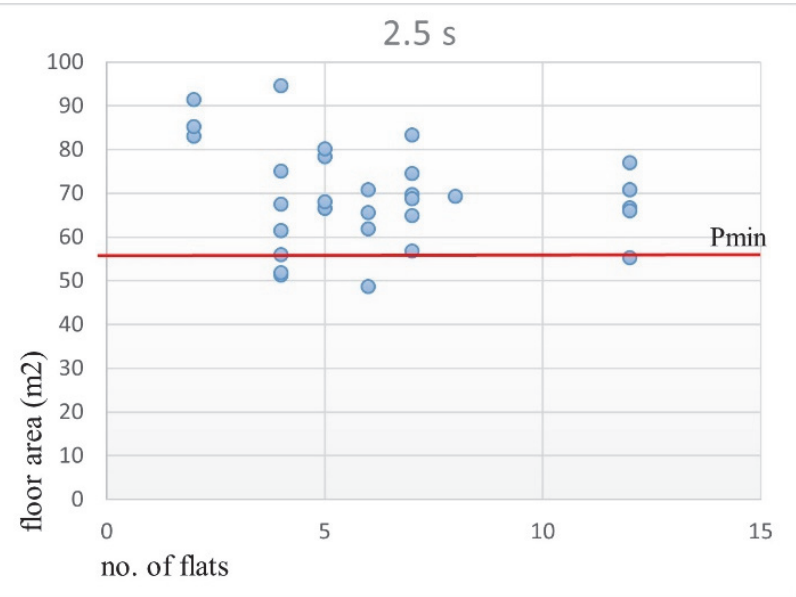

Figure 6 Review of the flat sizes within two and half-room apartment sample

The most common reasons for this phenomenon of apartment's area reduction are the imposed market/investor requirements that condition the architect to organize residential space in as small an area as possible. These apartments are usually designed for conventional family groups as well as for varying categories of family groups with temporality of housing as a fundamental feature. Investors' requirements for organizing the functions in such a small space are reflected in the final areas of flats that are usually used for oversized family structures. This approach results in residential development outside the norms and below the minimal requirements for human habitation. In order to maximize profits, quality of design is systematically disrupted, resulting in a non-functional apartment, below the minimal conditions for a healthy living environment.

The entrance position within the layout significantly affects the spatial arrangement of the apartment and an achieved level of flexibility. The central location of the entrance is optimal for flexibility. This position provides the shortest possible connections with other parts of the apartment. In this particular case, most of the examples 
meet the requirement for central positioning of the entrance (80,34\%, 421 units).

The installation grouping represents also an important initial item in flexible design. The centrally positioned technical core provides the greatest level of flexibility because the surrounding space can be organized in many different ways. However, the most common are apartments with peripherally positioned technical core $(91 \%, 477$ units), which reduces the opportunities for flexible arrangement of the functional zones. This stems from the fact that the position of certain living areas is caused by the position of technical cores. The offered alternative solutions are characterized by vague differentiation of functional zones within the flat.

The structural system as the rigid and unchanging part of housing units, also affects the degree of spatial flexibility. The current trend in design is characterized by increased construction of the building in the frame system (70,42\%, 369 units), while the choice of massive or composite structural system is in a smaller percentage. A comparison of the massive and skeletal (frame) structural system demonstrates that the massive system and its structural elements limit the flexibility and hinder the room formation in at least one direction. The frame system leaves a greater possibility of space distribution.
Tab. 5 provides an overview of the percentage share of dwellings. The percentage of apartments with a greater degree of flexibility (II degree, 20,04\%) is considerably lower than that of the apartments with a lower degree of flexibility (I degree, 79,96\%). A minor presence of the apartments with functional and spatial flexibility that would allow the acceptance of additional family functions in the extensive development phase is mainly the consequence of badly dimensioned residential space, which is below the minimum requirements of living comfort. This occurs due to complex local circumstances of design and construction, which largely stem from the poorly structured housing policy and market conditions that dictate a lower quality of housing construction.

In the end, it is important to emphasize that none of these factors can independently lead to the optimal solution. Rather, it is the result of a combination of numerous, interrelated factors whose interrelationship determines the degree of achieved flexibility [11]. Variability is still largely determined by the apartment size areas as it can be seen in this particular case. The problem of spatial deficits in most of the analysed examples implies reduction of the opportunity for flexibility and sustainability to a minimum.

Table $\mathbf{5}$ Specific spatial configuration and appropriate level of flexibility

\begin{tabular}{|c|c|c|c|c|}
\hline $\mathrm{N}^{\circ}$ & Residential building & $\begin{array}{l}\text { Total number of analyzed flats } \\
\text { per building }\end{array}$ & $\begin{array}{c}\mathrm{N}^{0} \text { of flats with I degree } \\
\text { of flexibility }\end{array}$ & $\begin{array}{l}\mathrm{N}^{\circ} \text { of flats with II degree of } \\
\text { flexibility }\end{array}$ \\
\hline 1 & Petra Vučinića str. and Trg Kralja Aleksandra & $19 \quad(100 \%)$ & $-(0 \%)$ & $19(100 \%)$ \\
\hline 2 & Generala Tranijea str. & $20(100 \%)$ & $12(60 \%)$ & $8(40 \%)$ \\
\hline 3 & Vojvode Tankosića str. & - & - & - \\
\hline 4 & Ćirila i Metodija str. & $16(100 \%)$ & $12(75 \%)$ & $4(25 \%)$ \\
\hline 5 & 7 juli str. & $8(100 \%)$ & $4(50 \%)$ & $4(50 \%)$ \\
\hline 6 & Radoja Dakića str. & $66(100 \%)$ & $60(90,90 \%)$ & $6(9,09 \%)$ \\
\hline 7 & Tome Roksandića str. & $13(100 \%)$ & $13 \quad 100 \%)$ & $-(0 \%)$ \\
\hline 8 & Radoja Dakića and Dimitrija Dragojevića str. & $84(100 \%)$ & $77(91,67 \%)$ & $7(8,33 \%)$ \\
\hline 9 & Vojvode Stepe str. & $20(100 \%)$ & $15(75 \%)$ & $5(25 \%)$ \\
\hline 10 & Dušanova str. & $7(100 \%)$ & $7(100 \%)$ & $-(0 \%)$ \\
\hline 11 & Somborska & $16(100 \%)$ & $16(100 \%)$ & $-(0 \%)$ \\
\hline 12 & Vojvode Mišića & $36(100 \%)$ & $24(67 \%)$ & $12(33 \%)$ \\
\hline 13 & Jeronimova str. & $20(100 \%)$ & $20(100 \%)$ & $-(0 \%)$ \\
\hline 14 & Primorska str. & $4(100 \%)$ & $4(100 \%)$ & $-(0 \%)$ \\
\hline 15 & Branka Krsmanovića & $48(100 \%)$ & $24(50 \%)$ & $24(50 \%)$ \\
\hline 16 & Vojvode Tankosića and Hajduk Stanka str. & $24(100 \%)$ & $24(100 \%)$ & $-(0 \%)$ \\
\hline 17 & Ućitelj Tasina & $35(100 \%)$ & $35(100 \%)$ & $-(0 \%)$ \\
\hline 18 & Ćirila i Metodija str. & $16(100 \%)$ & $12(75 \%)$ & $4(25 \%)$ \\
\hline 19 & Josifa Pančića str. & $36(100 \%)$ & $36(100 \%)$ & $-(0 \%)$ \\
\hline 20 & Jovana Skerlića str. & $36(100 \%)$ & $24(67 \%)$ & $12(33 \%)$ \\
\hline \multicolumn{2}{|c|}{ Total number of analyzed apartments } & $524(100 \%)$ & $419(79,96 \%)$ & $105(20,04 \%)$ \\
\hline
\end{tabular}

\section{CONCLUSION}

According to the adopted evaluation model previously defined in the research, the analysis of flexible apartment potentials in a representative example of contemporary residential architecture of the city of Nis (Southeastern Serbia) is implemented. Based on the obtained results, in the context of flexible housing, the observations on the current methodology of architectural design for a specific urban environment are represented. The current housing market conditions in Serbia, as well as legislative and regulatory framework of design and construction, have been also taken into consideration. 
Flexibility in the design is implemented to a lesser extent and mainly involves a multi-functional use of space without possibilities of spatial reorganization and increasing the number of rooms. The poor economic status of the users causes the family adjustment to housing conditions rather than the reverse. The economic situation that led to the extinction of giant construction companies and large architectural firms, allowed the fragmented construction companies and design offices to design and build in accordance with demands of investors, without considering all the necessary stages of design, or respecting minimal norms and requirements defined by valid legislative. The study emphasizes the importance of the architects' way of thinking during the design process, and additionally, the selected methods and strategies that can contribute to the realization of the goals of a flexible housing. Unfortunately, the last decade in Serbia was marked by the evident stagnation in research in the context of sustainable housing, bypassing the existing regulations of minimum requirements for living comfort as well as inadequate spatial organization as a consequence of weak education of designers. As a result, frequently, in both dimensional and functional terms, the apartment does not meet the family needs in either the extensive or the early stage of development.

Individual citizens are in a weak position in the interplay of forces in the housing market. The interests of the other parties-local authorities, builders, housing associations and developers-dominate, as the individuals find themselves unable to take a stand against the other, much stronger players. A nonselective market that accepts lower quality housing, low design prices coupled with a difficult financial situation that forces architects into overproduction are important negative factors influencing this situation. If methods of professional training and treatment are not found soon, the transition period may mark the towns with an inappropriate physical structure of the apartment, which will remain without a character of sustainability. The implementation of defined urban, architectural and construction regulations and standards requires a serious control conducted by the relevant administrative authorities, in order to prevent abuses and truly improve the quality of residential development.

\section{Acknowledgements}

The paper is a part of the project "Optimization of Architectural and Urban Planning and Design in Function of Sustainable Development in Serbia", funded by the Ministry of Education and Science, Republic of Serbia.

\section{REFERENCES}

[1] Kronenburg, R. (2007). Flexible: Architecture that responds to change. London, UK: Laurence King Publishing.

[2] Kubet, V. (2009). New aspects of the flexibility of housing. Nauka+Praksa, 12(1), 97-100.

[3] Slaughter, E. S. (2001). Design strategies to increase building flexibility. Building Research \& Information, 29(3), 208-217. https://doi.org/10.1080/09613210010027693

[4] Stoiljkovic, B. (2004). Fleksibilnost stanova namenjenih tržištu. Zbornik radova Građevinsko-arhitektonskog fakulteta, Niš, 20, 31-46.
[5] Bongaarts, J. (2001). Household size and composition in the developing world in the 1990s. Population Studies, 55, 263279. https://doi.org/10.1080/00324720127697

[6] Census of Population, Households and Dwellings in the Republic of Serbia 2011. (2012). Belgrade, Serbia: Statistical Office of the Republic of Serbia.

[7] Census of Population, Households and Dwellings in the Republic of Serbia 2002. (2003). Belgrade, Serbia: Statistical Office of the Republic of Serbia.

[8] Djordjevic, Lj. (2008). Promene u prosečnoj veličini domaćinstva u Srbiji u drugoj polovini 20. veka. Stanovništvo, 46(1), 41-69. https://doi.org/10.2298/STNV0801041D

[9] Damnjanovic, D. \& Gligorijevic, Z. (2010). Socijalno stanovanje - Prikaz stambenih politika Srbije i odabranih zemalja Evrope. Beograd, Srbija: Palgo Centar.

[10] Begovic, B. et al. (2010). Socijalno stanovanje u Srbiji. Beograd, Srbija: Službeni Glasnik Beograd.

[11] Moharram, L. A. (1980). A method for evaluating the flexibility of floor plans in multy-story housing (doctoral dissertation). University of Pennsylvania, USA.

[12] Zivkovic, M. \& Jovanovic, G. (2012). A method for evaluating the degree of housing unit flexibility in multifamily housing. FU Arch Civ Eng, 10(1), 17-32. https://doi.org/10.2298/FUACE1201017Z

[13] Ordinance on the Conditions and Standards for the Design of Residential Buildings and Flats. (2012). Belgrade, Serbia: Official Gazette RS no. 58/2012.

\section{Contact information:}

Milica ZIVKOVIC, Assistant Professor

(Corresponding author)

Faculty of Civil Engineering and Architecture,

Aleksandra Medvedeva 14, 18000 Nis, Serbia

E-mail: dia.milica@gmail.com

Slaviša KONDIC, Teaching Assistant

Faculty of Civil Engineering and Architecture,

Aleksandra Medvedeva 14, 18000 Nis, Serbia

E-mail: slavisa.kondic@gaf.ni.ac.rs

Milan TANIC, Associate Professor

Faculty of Civil Engineering and Architecture,

Aleksandra Medvedeva 14, 18000 Nis, Serbia

E-mail:milan.tanic@gaf.ni.ac.rs

Marija STAMENKOVIC, Assistant Professor

Faculty of Technical Sciences,

Knjaza Milosa 7, 38220 Kosovska Mitrovica, Serbia

E-mail: marija.stamenkovic@pr.ac.rs

Aleksandar KEKOVIC, Full Professor

Faculty of Civil Engineering and Architecture,

Aleksandra Medvedeva 14, 18000 Nis, Serbia

E-mail: aleksandar.kekovic@gaf.ni.ac.rs 